\title{
The Development of Local-Based Teaching Materials Using Inquiry Learning in Class IV of 105346 Public Elementary Schools Araskabu, School Year of 2019/2020
}

\author{
Khairunnisa Putri ${ }^{1}$, Phil. Ichwan Azhari ${ }^{2}$, R. Musrid ${ }^{3}$ \\ ${ }^{1}$ Postgraduate Program in Universitas Negeri Medan, Indonesia \\ ${ }^{2,3}$ Universitas Negeri Medan, Indonesia \\ chaaairunnisa92@gmail.com
}

\section{Abstract}

Nowadays when looking at the behavior of students in the learning process at school, it is known that a student learns because it is an obligation not a necessity. As a result, students do not understand the learning material delivered by the teacher. For this reason, a teacher is required to find the main problem of these problems so that the right solution can be found. This research is a research development (Research and Development). This development research was carried out to produce learning tools which would then be tested in class. Learning tools developed are learning tools with local-based teaching materials in Inquiry Learning. The results of observations through observation and interviews with teachers and students of Class IVSD Negeri 105346 Araskabu in the field showed that teaching and learning activities were almost completely dominated by teachers using conventional methods, namely lectures, notes and assignments. Activities carried out by students during the learning process include sitting neatly, listening to the teacher teach, taking notes, and doing questions. There are also many students who chat and enjoy their respective activities during the learning process. Most elementary school teachers consider themselves to be the introduction of knowledge. When teachers carry out the teaching and learning process in the classroom, learning activity is rarely found that involves students being actively involved, such as discussing, making discoveries, or testing a concept or theory using one of the learning approaches. Such learning will cause negative reactions for students, such as: (1) Students look lethargic, not enthusiastic and even sleepy; (2) Students find learning boring; (3) The results of learning are not in accordance with what is stated in the learning objectives. The negative reactions above lead to low student understanding because the methods used by the teacher are not in accordance with the characteristics of the students being faced.
Keywords

local-based; teaching materials, inquiry learning

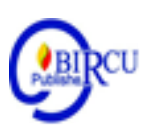

\section{Introduction}

Education is an important thing in human life. With education, humans can develop all their potential and existing skills according to their interests, talents and abilities. The success of educational goals is determined by the level of readiness to be able to implement all the things necessary for the education process to take place properly. This success departs from the educational process depending on how learning is carried out so that there is interaction between teachers and students. Teachers and students have a 
strategic position in improving the quality of learning. This is in accordance with the opinion of Prastowo (2013: 57) that learning means the process, method, act of learning, and the act of making people or living things learn.

Learning is a process or an effort to create learning conditions in optimally developing students' interests and talents, so that competencies and learning objectives can be achieved. In the learning process, learning and teaching interactions occur in certain conditions that involve students and teachers, including the environment. The learning process is a series of activities consisting of preparation, implementation and evaluation of learning. These three things are a complete series that cannot be separated. Teaching and learning preparation is the preparation of devices that support lessons, namely teaching materials and learning implementation plans. The readiness of students, both physically and mentally, is also important.

The implementation of the teaching and learning process is an event or event of interaction between educators and students which is expected to result in changes in students, from not being able to become capable, from not being educated to being educated, from not being competent to being competent. The essence of the teaching and learning process is its effectiveness. The level of learning effectiveness is strongly influenced by the behavior of educators and the behavior of students. Effective educator behavior, including teaching clearly, using a variety of learning methods, using a variety of media/educational aids.

According to Sagala (2011: 164), so far, learning that takes place tends to show monotonous and less varied learning. Teachers give more lectures (one-way learning interactions), and teaching materials or media have not been fully utilized. The teacher is not just a conveyor of material but more than that the teacher can be said to be the center of learning. As a regulator as well as an actor in the teaching and learning process, it is the teacher who directs how the teaching and learning process is carried out. Teachers must be able to make teaching more effective and interesting so that the learning material delivered will make students feel happy and feel the need to learn the lesson material. Besides the teacher, the success of achieving the learning objectives is determined by many factors including the available learning tools. Learning tools will really help teachers and students in an effort to understand the concepts of the material to be studied. Using appropriate learning tools in class, it is hoped that the learning objectives can be achieved. The learning device in question is a textbook or teaching material and a lesson plan.

Nowadays when looking at the behavior of students in the learning process at school, it is known that a student learns because it is an obligation not a necessity. As a result, students do not understand the learning material delivered by the teacher. For this reason, a teacher is required to find the main problem of these problems so that the right solution can be found.The main problem according to the author in learning is the use of learning methods or models and teaching materials used by teachers. Teachers still do not pay attention to the environment as a source of learning, teachers also have not linked the material with the real life of students.

The results of observations through observation and interviews with teachers and students of Class IVSD Negeri 105346 Araskabu in the field, showed that teaching and learning activities were almost completely dominated by teachers using conventional methods, namely lectures, notes and assignments. Activities carried out by students during the learning process include sitting neatly, listening to the teacher teach, taking notes, and doing questions. There are also many students who chat and enjoy their respective activities during the learning process. Most elementary school teachers consider 
themselves to be the introduction of knowledge. When teachers carry out the teaching and learning process in the classroom, learning activity is rarely found that involves students being actively involved, such as discussing, making discoveries, or testing a concept or theory using one of the learning approaches. Such learning will cause negative reactions for students, such as: (1) Students look lethargic, not enthusiastic and even sleepy; (2) Students find learning boring; (3) The results of learning are not in accordance with what is stated in the learning objectives. The negative reactions above lead to low student understanding because the methods used by the teacher are not in accordance with the characteristics of the students being faced.

\section{Review of Literatures}

\subsection{Learning Outcomes}

Learning as an individual activity is actually an individual stimulus sent to him by the environment. Learning is a type of change that is shown in changes in behavior, which are different from before the individual was in a learning situation and after taking similar actions. Learning is defined as a process of behavior change, due to individual interactions with the environment. Individuals can be said to have experienced a learning process, although in themselves there are only changes in behavior tendencies. These behavioral changes include knowledge, understanding, skills, attitudes, and so on that can or cannot be observed. Learning outcomes are a form of achievement students as well as a symbol of the success of educators in learning students (Yusuf in Sitorus (2019). According to Arsani (2020), learning is essentially a cognitive process that has the support of psychomotor functions. Low learning outcomes and students' critical thinking skills are also influenced by low student motivation (Utomo, 2020).

According to Siregar (2014: 45) learning is a mental / psychic activity in active interaction with the environment that results in changes in understanding knowledge, skills and attitude values. Psychologically, learning is a process of change, namely changes in behavior as a result of interaction with the environment in fulfilling their daily needs. Learning is a business process carried out by a person, as a result of his own experience in interaction with his environment (Slameto, 2003: 3). In line with the opinion of Djamarah (2010: 13) suggests that learning is a series of mental and physical activities to obtain a change in behavior as the results of individual experiences in interactions with their environment concerning cognitive, affective, and psychomotor.

The same thing stated by Sardiman (2004: 21) that learning will bring about a change in learning individuals. Change is not only related to the addition of knowledge, but also in the form of abilities, skills, attitudes, understanding, self-esteem, interests, character, and self-adjustment. Sudijono (2012: 42) defines learning as a change in behavior in individuals thanks to the interaction between individuals and individuals and individuals with the environment so that they are better able to interact with their environment.

Sudjana (2008: 51) states that learning is a process characterized by changes in a person. Change as a result of the learning process can be shown in various forms such as changes in knowledge, understanding, attitudes and behavior, skills, skills, habits and changes in other aspects that exist in individual learning. The same thing is expressed by Djamarah (2010: 12) formulating learning as a process in which behavior is generated or changed through training or experience. Therefore, learning takes place actively and integratively by using various forms of action to achieve goals. 
Meanwhile, Hamalik (2014: 27), learning is a modification or reinforcing behavior through experience. Learning is also a form of growth and change in a person that is expressed in new ways of behavior as a result of experiences. Learning is a serious effort, systematically, to utilize all the potential that is possessed both physically, mentally, five senses, brain or other body parts, as well as mental aspects such as intelligence, talents, interests, and so on. Learning is a process of effort carried out by a person to obtain a whole new change in behavior, as a result of his own experience in interaction with his environment.

\subsection{Definition of Textbook}

Textbook is a teaching material that is arranged and designed in such a way for the benefit of student learning. The approach in textbook learning uses student experience. According to Andi Prastowo (2012: 106) textbooks are teaching materials arranged systematically in language that is easily understood by students, according to their age and level of knowledge so that they can learn independently with minimal guidance from educators. The use of teaching materials in learning aims so that students can learn independently without or with a minimum from the teacher. In learning, the teacher is only a facilitator.

A similar view is expressed by Sukiman (2011: 131) which states that textbooks are part of a planned learning unit designed to help individual students achieve their learning goals. Students who have high speed in learning will master the material faster. Meanwhile, students who have a low learning speed can learn again by repeating parts that have not been understood until understood. The same thing is also explained by Azhar (2011: 65), learning textbooks are teaching materials arranged systematically and attractively which include material content, methods and evaluations that can be used independently to achieve the expected competencies.

Teaching textbook is the smallest unit of teaching and learning program, which is studied by students themselves individually or taught by students to themselves. Learning teaching materials are teaching materials that are arranged systematically and attractively which include material content, methods and evaluations that can be used independently in a kind of program package for learning purposes. Sungkono (2003: 86) states that a textbook learning is a teaching package that contains a unit of concept rather than learning material. Teaching Teaching materials is an individual teaching effort that allows students to master one unit of subject matter before he moves on to the next unit.

\subsection{Inquiry Learning}

Inquiry which in English means inquiry, or examination, investigation (Gulo, 2004: 84). Some opinions about the inquiry learning model, among others, according to Rusman (2012: 123), the inquiry learning model is a model that emphasizes learning experiences that encourage students to discover concepts and principles.Sumantri(1999: 164) states that the inquiry learning model is a way of presenting lessons that provide opportunities for students to find information with or without teacher assistance. The inquiry learning model is a learning process that gives students the opportunity to test and interpret problems in a systematic way that provides evidence-based conclusions. Furthermore, it is said that the inquiry learning model is a process of obtaining and obtaining information by making observations and / or experiments to find answers or solve problems to questions or formulas of the period by using critical and logical thinking skills.

The inquiry learning model or approach is a form of student-centered learning approach (student centered approach). The main characteristic of the inquiry approach is 
that it emphasizes maximum student activity to seek and find (placing students as learning subjects), all activities carried out by students are directed to seek and find their own answers to something being questioned so that it is expected to foster a confident attitude and develop the ability to think systematically, logically, and critically or develop intellectual abilities as part of a mental process (Sanjaya, 2006: 196).

Understanding the learning model Inquiry defined as a learning process based on search and discovery through a systematic thinking process. Knowledge is not a number of facts the result of remembering, but the result of discovering it yourself. Learning is basically a person's mental process that doesn't happen mechanically. Through this mental process, it is hoped that students will develop intellectually, mentally, emotionally, and personally. Therefore, in the learning planning process, the teacher is not preparing a number of materials to be memorized, but designing learning that allows students to find the material they must understand themselves.

\section{Research Methods}

This research is a research development (Research and Development). This development research was carried out to produce learning tools which would then be tested in class. Learning tools developed are learning tools with local-based teaching materials in Inquiry Learning.

This research was conducted in class IVSD Negeri 105346 Araskabu even semester of the 2019/2020 school year. The reason the researchers chose this school was because similar research had never been carried out at the school. Furthermore, thematic learning at SD Negeri 105346 Araskabum usesInquiry learning model which is a series of learning activities that involve all students' abilities to seek and investigate systematically, critically, logically, analytically, so that they can formulate their own findings confidently. By developing learning modules which are teaching materials that are arranged systematically and attractively that include material content, methods and evaluation that can be used independently in a kind of program package for learning purposes.

Learning outcomes are the abilities that students have after receiving their learning experiences. These abilities include cognitive, affective, and psychomotor aspects so far they are still low. The low student learning outcomes are due to the learning applied by the teacher is still conventional with learning dominated by teachers, passive students and always waiting for teacher orders, student interactions with students and teachers rarely occur. Data collection time starts from February to April 2020.

\section{Discussion}

Based on a review of the implementation and learning outcomes of Class IV SD Negeri 105346 Araskut it turns out that the fundamental problem that needs to be resolved is the low understanding of students' concepts which results in low thematic learning achievement. The low student achievement is a problem that must be found for alternative solutions.

One thematic learning model that emphasizes the cognitive aspects of students, prioritizes student activity, and emphasizes the importance of using problems in starting learning is local-based teaching materials using inquiry learning. 
Table 1. RevisionLocal-Based Textbooks Using Inquiry LearningProblem-based Expert Validation Results

\begin{tabular}{|c|c|c|}
\hline Before it was revised & After being revised & Reason for revising \\
\hline $\begin{array}{l}\text { Read again the problem } \\
\text { with the locally based } \\
\text { teaching materials using the } \\
\text { inquiry lesson above! The } \\
\text { pictures on locally based } \\
\text { teaching materials using } \\
\text { inquiry learning seem to } \\
\text { have to be adapted to } \\
\text { elementary school age } \\
\text { children }\end{array}$ & $\begin{array}{l}\text { Reread the problems in } \\
\text { locally based teaching } \\
\text { materials using inquiry } \\
\text { learning! }\end{array}$ & $\begin{array}{l}\text { Revision of some } \\
\text { questions from locally } \\
\text { based teaching materials } \\
\text { using inquiry learning on } \\
\text { the instrument so that } \\
\text { there is no wrong } \\
\text { interpretation }\end{array}$ \\
\hline $\begin{array}{l}\text { Write down the names and } \\
\text { things you know about } \\
\text { some examples of the } \\
\text { various job themes! }\end{array}$ & $\begin{array}{l}\text { Write down the names and } \\
\text { things you know about the } \\
\text { school environment and at } \\
\text { home about the themes of } \\
\text { various jobs! }\end{array}$ & \\
\hline $\begin{array}{l}\text { Write down the names and } \\
\text { things you know about the } \\
\text { various job themes! }\end{array}$ & $\begin{array}{l}\text { Write down the names and } \\
\text { things you know about the } \\
\text { theme of the various jobs } \\
\text { that are asked in the } \\
\text { picture! }\end{array}$ & \\
\hline
\end{tabular}

Table 2. Revision of Test Instruments and Learning Devices for Expert Validation Results

\begin{tabular}{|c|c|l|l|}
\hline No. & Revised & \multicolumn{1}{|c|}{ Observer Notes } & \multicolumn{1}{c|}{ After being revised } \\
\hline 1 & RPP & $\begin{array}{l}\text { It has not been seen in the } \\
\text { initial activity which contains } \\
\text { an explanation of how to give a } \\
\text { score if students excel. } \\
\text { Indicators do not require } \\
\text { students to reason and use } \\
\text { many ways to solve problems } \\
\text { Students less } \\
\text { maximum work in groups }\end{array}$ & $\begin{array}{l}\text { At the beginning of each } \\
\text { meeting, the researcher first } \\
\text { explains the purpose of how to } \\
\text { calculate the increase score } \\
\text { Change the indicators in the } \\
\text { RPP in step 3 into indicators } \\
\text { that see various ways of } \\
\text { solving problems } \\
\text { The activity sheet is given a } \\
\text { problem that has many ways } \\
\text { of solving }\end{array}$ \\
\hline
\end{tabular}




\begin{tabular}{|c|c|l|l|}
\hline No. & Revised & \multicolumn{1}{|c|}{ Observer Notes } & \multicolumn{1}{c|}{ After being revised } \\
\hline 2 & Test & $\begin{array}{l}\text { The time needed to work on } \\
\text { the problem is less } \\
\text { Question there is still no } \\
\text { demand for students to use } \\
\text { various problem solving } \\
\text { methods. }\end{array}$ & $\begin{array}{l}\text { Add time and } 60 \text { minutes to } 80 \\
\text { minutes } \\
\text { Question test designed } \\
\text { which asks various ways of } \\
\text { solving problems }\end{array}$ \\
\hline 3 & $\begin{array}{l}\text { Student } \\
\text { activities }\end{array}$ & $\begin{array}{l}\text { Students still give less } \\
\text { activity on subject matter }\end{array}$ & $\begin{array}{l}\text { Change the way of delivery } \\
\text { and provide input to students }\end{array}$ \\
\hline
\end{tabular}

Table 3. Teacher Ability to Manage Pappendix

\begin{tabular}{|c|c|c|c|c|c|c|c|}
\hline & \multirow{2}{*}{ NO } & \multirow{2}{*}{ Observation Category } & \multicolumn{5}{|c|}{$\begin{array}{l}\text { Score of Teacher Activities in } \\
\text { Learning }\end{array}$} \\
\hline & & & $\begin{array}{c}\mathbf{R P P} \\
\mathbf{1}\end{array}$ & $\begin{array}{c}\mathbf{R P P} \\
2\end{array}$ & $\begin{array}{c}\mathbf{R P P} \\
\mathbf{3}\end{array}$ & $\begin{array}{c}\text { RPP } \\
4\end{array}$ & Flat \\
\hline & 1 & Doing daily activities & 5 & 5 & 5 & 5 & 5 \\
\hline & 2 & Convey Purpose & 4 & 4 & 4 & 5 & 4.25 \\
\hline $\mathbf{W}$ & 3 & Generating initial knowledge & 4 & 5 & 5 & 5 & 4.75 \\
\hline \multirow{2}{*}{$\begin{array}{l}\mathbf{A} \\
\mathbf{L}\end{array}$} & 4 & Organizing students & 4 & 4 & 4 & 4 & 4 \\
\hline & 5 & $\begin{array}{l}\text { Provide facilities and } \\
\text { infrastructure }\end{array}$ & 4 & 4 & 4 & 4 & 4 \\
\hline \multirow[b]{3}{*}{ I } & 1 & Stimulate students & 3 & 4 & 5 & 5 & 4.25 \\
\hline & 2 & Providing Facts / Situations & 4 & 4 & 4 & 4 & 4 \\
\hline & 3 & Find / form questions & 4 & 4 & 4 & 4 & 4 \\
\hline $\mathbf{N}$ & 4 & Understand the questions & 3 & 3 & 4 & 4 & 3.5 \\
\hline $\mathbf{T}$ & 5 & Plan for Completion & 3 & 3 & 3 & 4 & 3.25 \\
\hline \multirow[t]{3}{*}{ I } & 6 & Solving Problems & 3 & 3 & 3 & 3 & 3 \\
\hline & 7 & Role in student performance & 2 & 3 & 4 & 3 & 3 \\
\hline & 8 & Material summary & 4 & 4 & 4 & 4 & 4 \\
\hline
\end{tabular}




\begin{tabular}{|c|c|l|c|c|c|c|c|}
\hline \multirow{2}{*}{} & \multirow{2}{*}{ NO } & \multirow{2}{*}{ Observation Category } & \multicolumn{5}{|c|}{ Score of Teacher Activities in } \\
& & & $\begin{array}{c}\text { RPP } \\
\mathbf{1}\end{array}$ & $\begin{array}{c}\text { RPP } \\
\mathbf{2}\end{array}$ & $\begin{array}{c}\text { RPP } \\
\mathbf{3}\end{array}$ & $\begin{array}{c}\text { RPP } \\
\mathbf{4}\end{array}$ & Flat \\
\cline { 4 - 8 } & & & 4 & 5 & 5 & 5 & 4.75 \\
\hline End & 1 & Conduct an Evaluation & 4 & 5 & 4 & 5 & 4.5 \\
\cline { 2 - 8 } & 2 & Doing daily activities & 55 & 60 & 62 & 64 & 60.25 \\
\hline & & Total score & \multicolumn{5}{|c|}{$\mathbf{2 4 1} \mathbf{1 0 0 / 3 0 0}=\mathbf{8 0 . 3 3 \%}$} \\
\hline
\end{tabular}

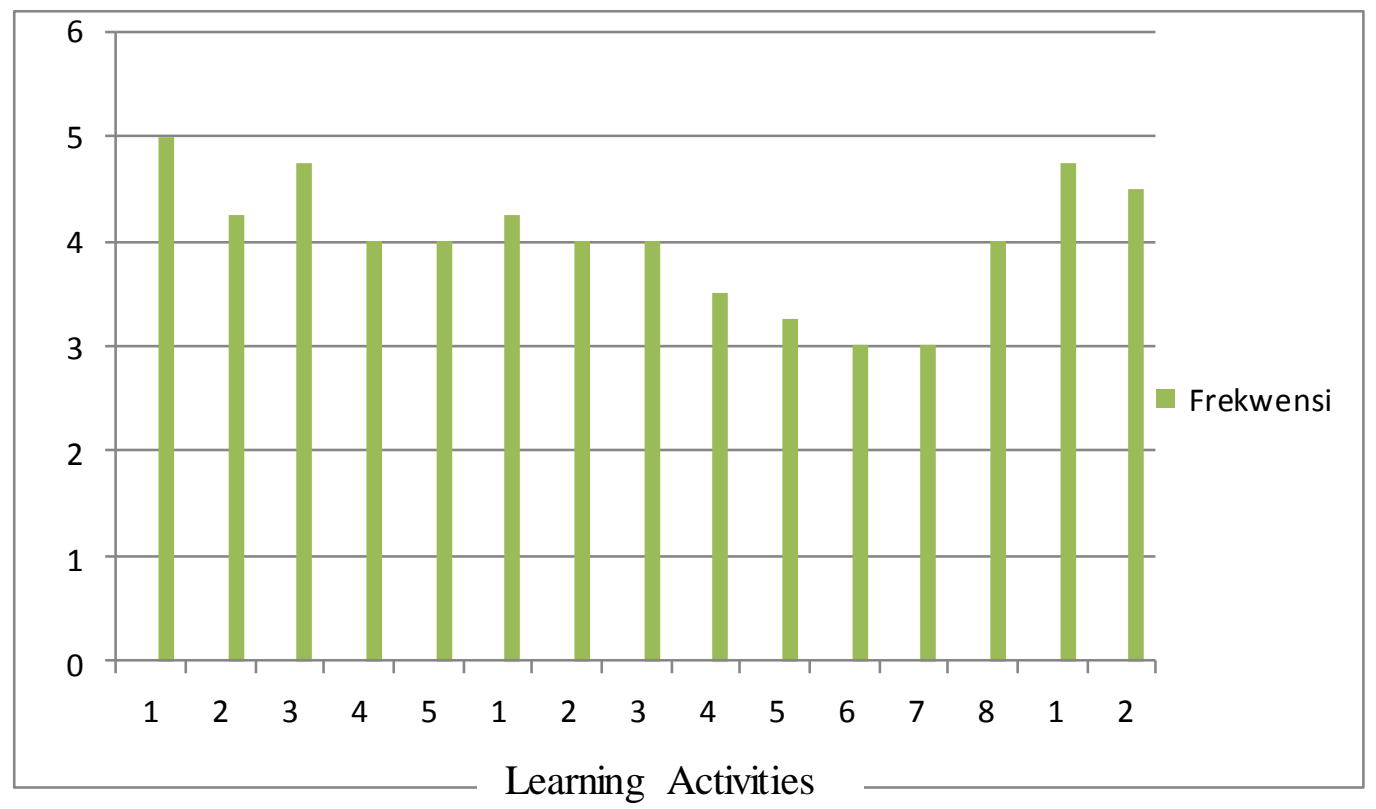

Figure 1. The Value of the Teacher's Ability to Manage Learning

Table 4. Levels of Student Activity Experiment I

\begin{tabular}{|c|c|c|c|}
\hline \multirow[t]{2}{*}{ No. } & \multirow[t]{2}{*}{ Observation Category } & $\begin{array}{l}\text { Level of Student } \\
\text { Activity }(\%)\end{array}$ & \multirow{2}{*}{$\begin{array}{c}\text { Tolerance Limit } \\
(\%)\end{array}$} \\
\hline & & meeting & \\
\hline 1 & $\begin{array}{l}\text { Listening / paying attention to the } \\
\text { teacher's explanation }\end{array}$ & 16.1 & $5 \% \leq \mathrm{P} \leq 15 \%$ \\
\hline 2 & $\begin{array}{l}\text { Read / understand the problems } \\
\text { that exist in LAS student books }\end{array}$ & 22.3 & $15 \% \leq \mathrm{P} \leq 25 \%$ \\
\hline
\end{tabular}




\begin{tabular}{|c|l|c|c|}
\hline 3 & $\begin{array}{l}\text { Writing / Troubleshooting / finding } \\
\text { ways of solving } \\
\text { ( Discuss / ask friends / teachers }\end{array}$ & 24.1 & $25 \% \leq \mathrm{P} \leq 35 \%$ \\
\hline 5 & Present work results & 13.4 & $20 \% \leq \mathrm{P} \leq 30 \%$ \\
\hline 6 & $\begin{array}{l}\text { Student behavior that is not } \\
\text { relevant to teaching and learning }\end{array}$ & 2.7 & $0 \% \leq \mathrm{P} \leq 5 \%$ \\
\hline
\end{tabular}

For more details, it can be seen that an overview of the percentage of student activity during learning is presented in the following figure:

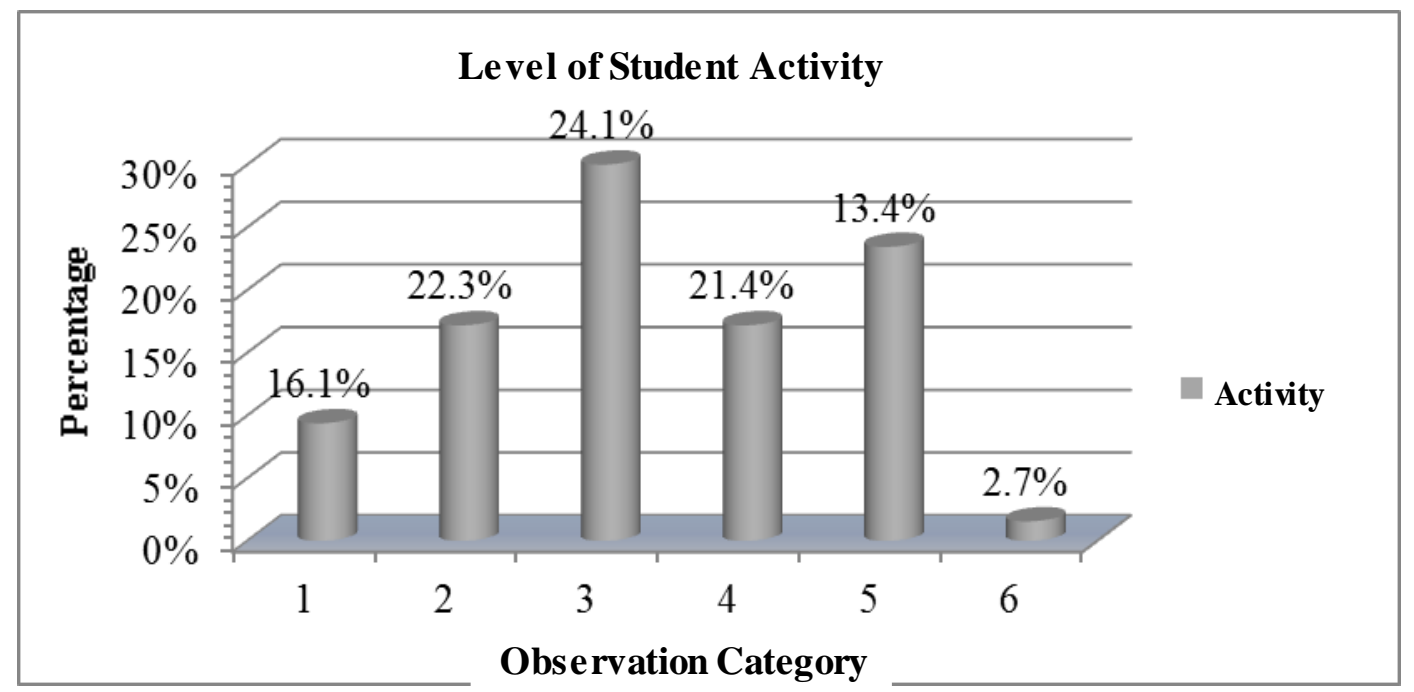

Figure 2. Levels of Student Activity

Information:

1. Listening / paying attention to the teacher's explanation

2. Read student books and relevant sources / understand the problem

3. Write / plan problem solving / solve problems / draw conclusions.

4. Conducting discussions / forming groups

5. Percentage of work results / giving responses to presentation of work results

6. Student behavior that is not relevant to teaching and learning activities.

Table 5. Student Learning Outcomes in Trials

\begin{tabular}{|c|c|c|c|c|}
\hline No. & Average Score & Criteria & Total & Percentage (\%) \\
\hline 1 & $\mathbf{6 5 \%} \leq \mathrm{KB} \leq \mathbf{1 0 0} \%$ & Completed & 29 & $\mathbf{8 0 . 5 6}$ \\
\hline 2 & $0 \% \leq \mathrm{KB}<65 \%$ & Not & 7 & 19.44 \\
\hline
\end{tabular}


Based on the data in Table 4.6 above, classical completeness has reached $80.56 \%$. So the classical learning outcomes are not yet complete.

Table 6. Teacher Ability to Manage Pappendix

\begin{tabular}{|c|c|c|c|c|c|c|c|}
\hline & \multirow{2}{*}{ NO } & \multirow{2}{*}{ Observation Category } & \multicolumn{5}{|c|}{$\begin{array}{c}\text { Score of Teacher Activities in } \\
\text { Learning }\end{array}$} \\
\hline & & & $\begin{array}{c}\mathbf{R P P} \\
1\end{array}$ & $\begin{array}{c}\text { RPP } \\
2\end{array}$ & $\begin{array}{c}\text { RPP } \\
3\end{array}$ & $\begin{array}{c}\text { RPP } \\
4\end{array}$ & $\begin{array}{l}\text { Avera } \\
\text { ge }\end{array}$ \\
\hline \multirow{2}{*}{$\begin{array}{l}\mathbf{O} \\
\mathbf{P}\end{array}$} & 1 & Doing daily activities & 5 & 5 & 5 & 5 & 5 \\
\hline & 2 & Convey Purpose & 4 & 5 & 5 & 5 & 4.75 \\
\hline \multirow{2}{*}{$\begin{array}{l}\mathbf{N} \\
\mathbf{I} \\
\mathbf{N}\end{array}$} & 3 & Generating initial knowledge & 5 & 5 & 5 & 5 & 5 \\
\hline & 4 & Organizing students & 4 & 4 & 5 & 5 & 4.5 \\
\hline G & 5 & $\begin{array}{l}\text { Provide facilities and } \\
\text { infrastructure }\end{array}$ & 4 & 5 & 5 & 5 & 4.75 \\
\hline \multirow[b]{3}{*}{$\mathbf{C}$} & 1 & Stimulate students & 5 & 5 & 5 & 5 & 5 \\
\hline & 2 & Providing Facts / Situations & 5 & 4 & 4 & 5 & 4.5 \\
\hline & 3 & Find / form questions & 5 & 5 & 4 & 5 & 4.75 \\
\hline \multirow[t]{5}{*}{$\mathbf{O}$} & 4 & Understand the questions & 4 & 4 & 5 & 5 & 4.5 \\
\hline & 5 & Plan for Completion & 5 & 4 & 4 & 4 & 4.25 \\
\hline & 6 & Solving Problems & 5 & 5 & 5 & 5 & 5 \\
\hline & 7 & Role in student performance & 4 & 5 & 5 & 5 & 4.75 \\
\hline & 8 & Material summary & 4 & 4 & 5 & 5 & 4.5 \\
\hline \multirow{4}{*}{$\begin{array}{l}\mathbf{E} \\
\mathbf{N} \\
\mathbf{D}\end{array}$} & 1 & Conduct an Evaluation & 4 & 5 & 5 & 5 & 4.75 \\
\hline & 2 & Doing daily activities & 4 & 5 & 5 & 5 & 4.75 \\
\hline & & Total score & 67 & 70 & 72 & 74 & 70.8 \\
\hline & & Percentage of Average score & \multicolumn{5}{|c|}{$283 \times 100 / 300=94.33 \%$} \\
\hline
\end{tabular}




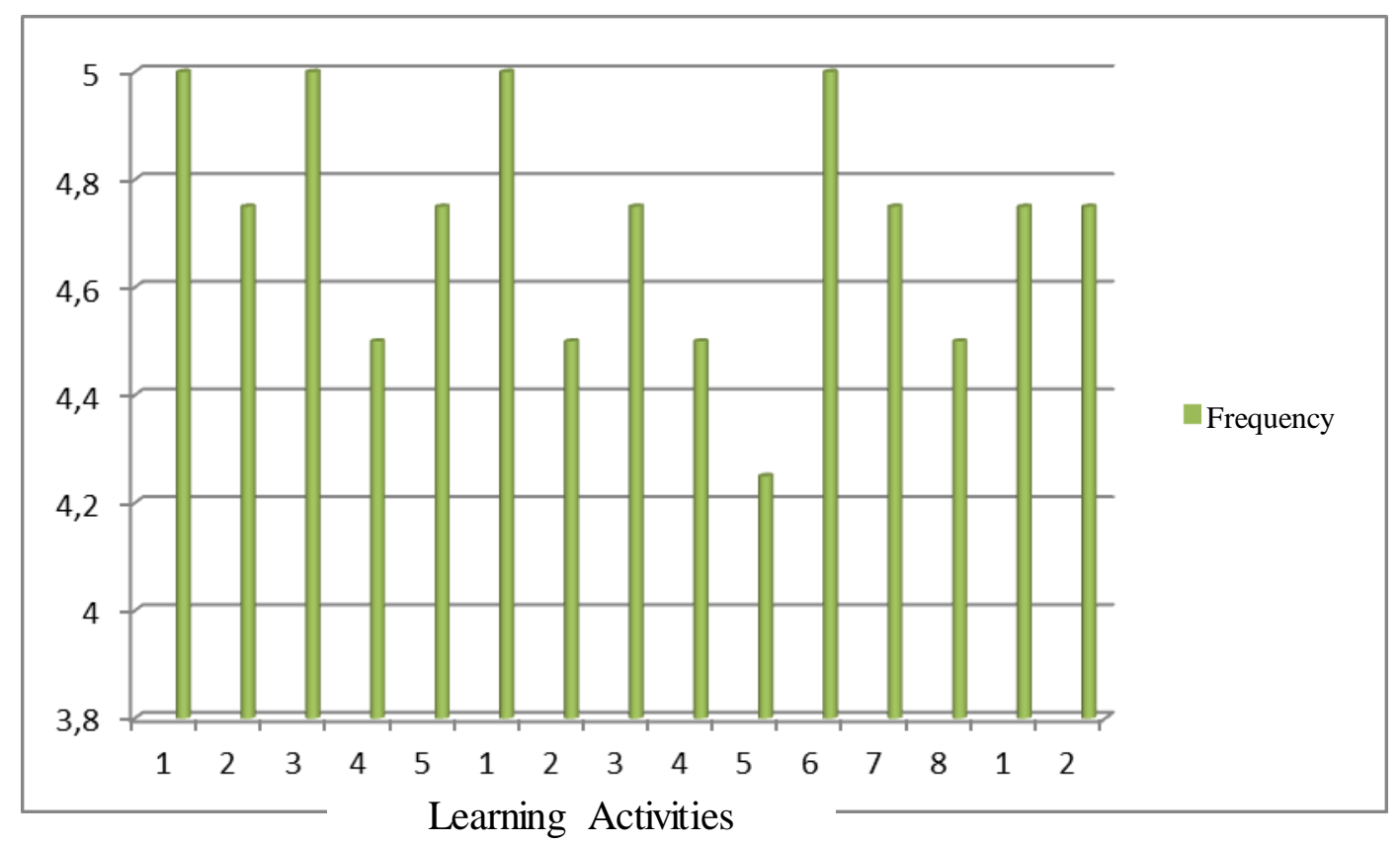

Figure 3. Value of Teacher Ability to Manage Learning

Table 7. Student Activity Levels in Trial II

\begin{tabular}{|c|l|c|c|}
\hline \multirow{2}{*}{ No. } & \multicolumn{1}{|c|}{ Observation Category } & $\begin{array}{c}\text { Level of } \\
\text { Student } \\
\text { nativin }\end{array}$ & \multirow{2}{*}{$\begin{array}{c}\text { Tolerance Limit } \\
\text { meeting }\end{array}$} \\
\hline 1 & $\begin{array}{l}\text { Listening / paying attention to the teacher's } \\
\text { explanation }\end{array}$ & 12.50 & $5 \% \leq \mathrm{P} \leq 15 \%$ \\
\hline 2 & $\begin{array}{l}\text { Read / understand the problems that exist in } \\
\text { LAS student books }\end{array}$ & 18.75 & $15 \% \leq \mathrm{P} \leq 25 \%$ \\
\hline 3 & $\begin{array}{l}\text { Write / Solve problems / find ways of } \\
\text { solving problems / draw conclusions }\end{array}$ & 25 & $25 \% \leq \mathrm{P} \leq 35 \%$ \\
\hline 4 & Discuss / ask friends / teachers & 19.65 & $10 \% \leq \mathrm{P} \leq 20 \%$ \\
\hline 5 & Present work results & 24.11 & $20 \% \leq \mathrm{P} \leq 30 \%$ \\
\hline 6 & $\begin{array}{l}\text { Student behavior that is not relevant to } \\
\text { teaching and learning activities }\end{array}$ & 0.00 & $0 \% \leq \mathrm{P} \leq 5 \%$ \\
\hline
\end{tabular}


For more details, it can be seen that an overview of the percentage of student activity during learning is presented in the following figure:

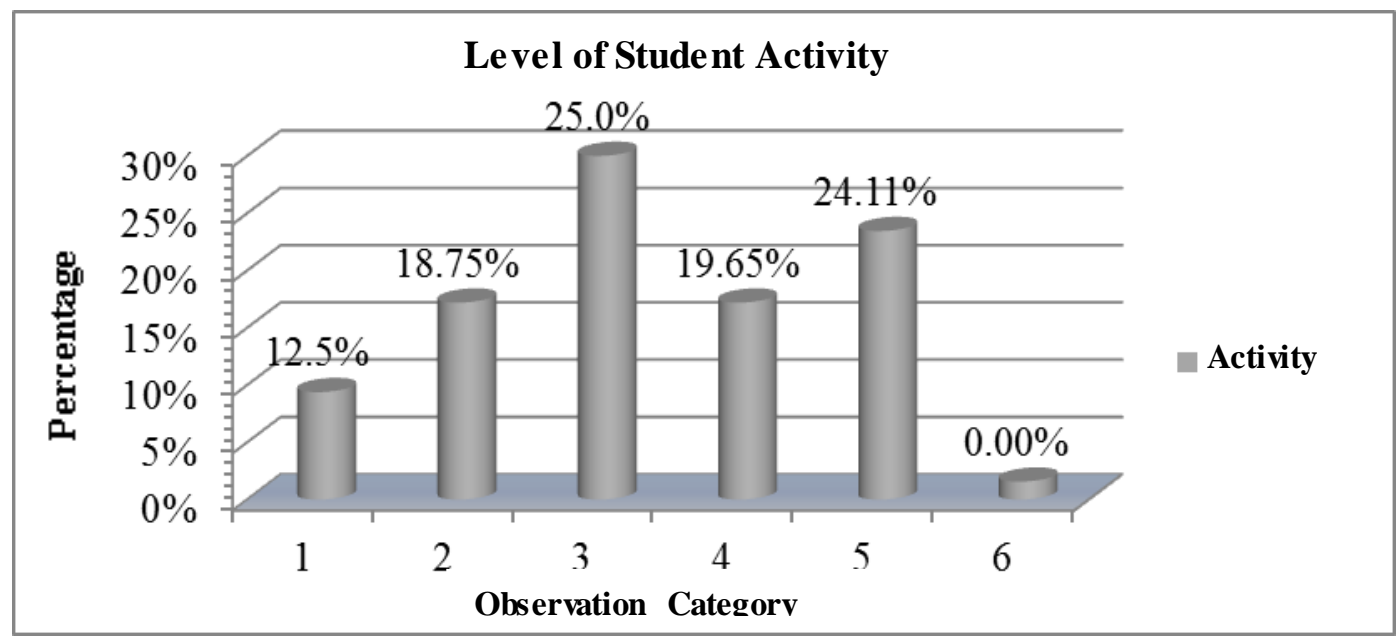

Figure 4. Level of Student Activity

Information:

1. Listening / paying attention to the teacher's explanation

2. Read student books and relevant sources / understand the problem

3. Write / plan problem solving / solve problems / draw conclusions.

4. Conducting discussions / forming groups

5. Percentage of work results / giving responses to presentation of work results

6. Student behavior that is not relevant to teaching and learning activities.

Table 8. Student Learning Outcomes in Trial II

\begin{tabular}{|c|c|c|c|c|}
\hline No. & Average Score & Criteria & total & Percentage (\%) \\
\hline 1 & $\mathbf{6 5 \%} \leq \mathrm{KB} \leq \mathbf{1 0 0} \%$ & Completed & 33 & 91.67 \\
\hline 2 & $0 \% \leq \mathrm{KB}<65 \%$ & Not & 3 & 8.33 \\
\hline
\end{tabular}

Based on the data in the table above, classical completeness has reached $91.67 \%$. So that the classical learning outcomes are complete.

Table 9. Posttest Results of Students Who Have Successful Trials I and II

\begin{tabular}{|c|c|c|}
\hline & \multicolumn{2}{|c|}{ Percentage (\%) } \\
\hline Postes & $\begin{array}{c}\text { Successful student learning } \\
\text { outcomes (\%) }\end{array}$ & $\begin{array}{c}\text { Unsuccessful student } \\
\text { learning outcomes (\%) }\end{array}$ \\
\hline Trial I & 80.56 & 19.44 \\
\hline Trial II & 91.67 & 8.33 \\
\hline
\end{tabular}


Based on Table 4.9 above, the percentage of student learning outcomes who succeeded in the post-test I test was $80.56 \%$ and in the second trial it was $91.67 \%$. This shows that the percentage of student learning outcomes who succeeded in increased by $11.11 \%$.

\section{Conclusion}

Based on the results of the analysis and discussion in this study, the following conclusions are presented:

1. The ability of the teacher to manage learning using locally based learning tools using inquiry learning developed in the first trial was in good criteria, and in the second trial it was in a good criterion too. The application of locally based textbooks using inquiry learning can improve the ability of teachers to manage learning after passing trial I and II, it can be seen from the average observed value is 25.9 or $94.44 \%$. In the second trial, the teacher's ability to manage learning with a mean score of 28.8 or $97.22 \%$ (very good). Giving apperception and motivation to students before exposing students to a problem is an effective early stage to foster positive attitudes during the learning process. Group learning is a suitable strategy for improving student reasoning. Students are more provoked to use their reasoning power optimally through expressing their ideas and how to respect their colleagues 'arguments, so that students can evaluate themselves and their colleagues' arguments objectively.

2. The application of locally-based textbooks using inquiry learning can increase the level of active student activity in learning. This can be seen from the results of observations of student active activity, where in the first trial there were 4 categories of 6 categories of observations of active student activity that were not within the specified tolerance limits or the level of student active activity. and in the second trial the observation of students' active activity in all categories was within the specified tolerance limit or the level of student active activity. In order for student activity to develop more, during the learning process it is hoped that students are actively involved in carrying out activities,

3. The effectiveness of the learning tools developed using locally based books using inquiry learning can be seen that the classical completeness score is $91.67 \%$ when viewed from the success of the learning outcomes at least moderate. This has exceeded the predetermined tolerance limit, which is at least $85 \%$ in moderate criteria. In order for student abilities to be more developed, during the learning process it is expected that students are actively involved in carrying out activities, for example students have discussions with colleagues and with teachers about problems so that can construct and evaluate their own arguments. 


\section{References}

Abidin, Y. (2014). Desain sistem pembelajaran dalam Konteks kurikulum 2013.Bandung: Refika Aditama.

Agung S, Leo. (2015). The Development of Local Wisdom-Based Social Science Learning Model with Bengawan Solo as the Learning Source. American International Journal of Social Science. 2325-4165. Vol. 4, No.4. 10 Agustus 2013. www.aijssnet.com

Amri, Sofan. (2013). Pengembangan dan Model Pembelajaran dalam Kurikulum 2013. Prestasi Pustakarya. Jakarta.

Akbar, S. (2013). Instrumen Perangkat Pembelajaran. Bandung: Remaja Rosdakarya.

Ali Imran. (1995), Pembinaan Guru di Indonesia.Jakarta : Pustaka Jaya.

Arikunto, S. (2006).Dasar-Dasar Evaluasi Pendidikan (Edisi Revisi). Bandung: Bumi Aksara.

Arifin, Z. (2011). Penelitian Pendidikan: Metode dan Paradigma Baru. Bandung: Remaja Rosdakarya.

Arends Richard I. (2008). Learning to Teach: Belajar untuk Mengajar, Yogyakarta: Pustaka Pelajar.

Arief S. Sadimandkk. (2011). Media Pendidikan: Pengertian, Pengembangan dan Pemanfaatannya. Jakarta: Rajawali Press.

Arsani, et.al (2020). Differences in Motivational Orientation in Physical Education in terms of Gender Differences. Budapest International Research and Critics in Linguistics and Education (BirLE) Journal Volume 3 (3): 1428-1434.

Arsyad, A. (2002). Media Pembelajaran, edisi 1. Jakarta: PT. Raja Grafindo Persada.

Aryani, Ine Kusuma dan Susantim, Markum. (2010). Pendidikan Kewarganegaraan Berbasis Nilai. Bogor: Ghalia Indonesia.

Asyhar, R. (2012). Kreatif Mengembangkan Media Pembelajaran. Jakarta: Gaung Persada Press.

Arief S. Sadiman. (2011). Media Pendidikan. Jakarta: Rajawali Pers.

Azhar Arsyad. (2011). Media Pembelajaran. Jakarta: Rajawali Pers.

Djamarah, dkk.(2010). Strategi Belajar Mengajar. Jakarta: RinekaCipta.

Undang-Undang Republik Indonesia Nomor 20 Tahun 2003 tentang Sistem Pendidikan Nasional. Jakarta: Cemerlang Publisher.

Dimyati dan Mudjiono.(2006). Belajar dan Pembelajaran. Jakarta : PT. Rineka Cipta

Gulo, W. (2004). Strategi Belajar Mengajar. Jakarta: Gramedia Widiasarana Indonesia.

Hamalik,O. (2014). Proses Belajar Mengajar. Jakarta: Bumi Aksara.

Haryanto. (2004). Sains Untuk Sekolah Dasar Kelas V. Jakarta: Erlangga.

Handika, I \& Wangid, M. N. (2013). Pengaruh Pembelajaran Berbasis Masalah Terhadap Penguasaan Konsep Dan Keterampilan Proses Sains SiswaKelas V. Jurnal Prima Edukasia.Vol.1, No.1.handika@ymail.com

Husamah dan Setyningrum. Y. (2013). Desain Pembelajaran Berbasis Pencapaian Kompetensi. Jakarta: Prestasi Pustakaraya.

Ikhsan, dkk. (2016), Pengembangan Modul Berbasis Inkuiri Terbimbing Pada Materi Sistem Gerak Manusia Untuk Meningkatkan Hasil Belajar Siswa.Jurnal Inkuiri. ISSN: 2252-7893, 5(1) 133-142.

Ilham, H. dan Muhammad, N.W. (2013). Pengaruh Pembelajaran Berbasis Masalah Terhadap Penguasaan Konsep dan Ketrampilan Proses Sains Siswa Kelas V.Jurnal Vol.2, No. 4. Prima Edukasia.

Laksono, T. (2015). Memahami Penggunaan Ilmu Ekonomi dalam Manajemen Rumah Sakit. Yogyakarta: Gadjah Mada University Press. 
Laulik, Nikmatul. 2010. Penerapan Metode Inkuiri Untuk Meningkatkan Hasil Belajar Pkn Siswa Kelas III SDN Petung 1 Kecamatan Pasuruan. Pasuruan: UT PGSD.

Majid, Abdul. (2008). Perencanaan Pembelajaran: Mengembangkan Standar Kompetensi Guru. Rosdakarya. Bandung.

Manalu, A. (2018). Pengaruh Model Pembelajaran Inkuiri Terbimbing Terhadap Pengetahuan Prosedural Siswa. Jurnal Suluh Pendidikan FKIP-UHN Volume-5, Edisi-1, Maret 2018. andrifis@ymail.com

Meika, dkk. (2016), Pengembangan modul berbasis inquiry lesson untuk meningkatkan dimensi konten pada literasi sains. Jurnal Inkuiri. ISSN: 2252-7893, 5,(3) 90-103.

Mirantika, dkk. (2015), Pengembangan modul pembelajaran materi fluida statis dengan strategi inkuiri terbimbing. Jurnal Pendidikan Fisika FKIP Unila. ISSN: 2324-7809, 2 (5) 46-52.

Mulyasa. E. (2008). Kurikulum Berbasis Kompetensi. Bandung: PT. Remaja Rosdakarya. . (2007). Standar Kompetensi dan Sertifikasi Guru. Bandung: PT. Remaja Rosdakarya.

Munadi Y. (2012). Media Pembelajaran. Jakarta: Gaung Persada Press.

Ni'mah, S. (2016). Lembar Kerja Mahasiswa Berbasis Inkuiri Terbimbing Untuk Meningkatkan Keterampilan Proses Sains Mahasiswa, Lentera Jurnal Pendidikan 11 (2), Desember 2016.

Parkay, Forrest W \& Beverly Hardcastle Stanford.(2011). Menjadi Seorang Guru. Terjemahan Wasi Dewanto. Jakarta: PT. Indeks.

Peraturan Menteri Pendidikan Nasional Republik Indonesia Nomor 22 Tahun 2006 Tentang Standar Isi Untuk Satuan Pendidikan Dasar Dan Menengah.

Peraturan Menteri Pendidikan Nasional Republik Indonesia Nomor 23 Tahun 2006 Tentang Standar Kompetensi Lulusan Untuk Satuan Pendidikan Dasar Dan Menengah.

Peraturan Pemerintah Republik Indonesia Nomor 19 Tahun 2005 Tentang Standar Nasional Pendidikan.

Prastowo A. (2012). Panduan Kreatif Membuat Bahan Ajar Inovatif. Yogyakarta: Diva Press.

Prastowo A. (2013). Pengembangan Bahan Ajar Tematik Panduan Lengkap Aplikatif. Yogyakarta: DIVA Press.

Prihatin, dkk. (2017). Pengembangan Modul Berbasis Inkuiri terbimbing Pada Materi Jamur Untuk Meningkatkan Kemampuan Berpikir Kritis Siswa Kelas X SMA Negeri 1 Cepogo Boyolali”. Jurnal Pendidikan IPA Volume-6, No.1, 2017. inkuiri@fkip@uns.ac.id

Rahayu, dkk.(2014). Kinerja Regulator Penyiaran Indonesia: Penilaian atas Derajat Demokrasi, Profesionalitas, dan Tata Kelola. Yogyakarta: Pemantau Regulasidan Regulator Media (PR2Media).

RemziyeErgul. (2011).The effects of inquiry-based science teaching on elementary School students' science process Skills and science attitudes. Bulgarian Journal of Science and Education Policy (BJSEP), Volume 5, Number 1, 2011.

Rina, R. dan Endang W.L.FX. (2015). Pengembangan Perangkat Pembelajaran IPA Berbasis Problem Based Learning di SMP.Jurnal Kependidikan, 45 (1): 30.

Rusman. (2012). Model - Model Pembelajaran.Depok : PT RajagrafindoPersada.

Sanjaya, W. (2006). Strategi Pembelajaran berorientasi Standar Proses pendidikan.Jakarta: Kencana Pranada media Group.

Sanjaya, W. (2009). Strategi pembelajaran berorientasi standar pendidikan. Jakarta. Fajar Kencana. 
Sanjaya, A. (2014). Penerapan Pendekatan Inkuiri Terbimbing Untuk Meningkatkan Keterampilan Proses Sains Pada Pembelajaran Ipa Materi Peristiwa Alam. Jakarta: Universitas Pendidikan Indonesia.

Sardiman, A.M. (2004). Interaksi dan Motivasi Belajar Mengajar. Jakarta: PT. Raja Grafindo.

Slameto, (2003).Belajar dan Faktor-Faktor Yang mempengaruhinya. Jakarta: Rineka Cipta.

Sinaga, B. (2007). Pengembangan Model Pembelajaran Matematika Berdasarkan Masalah Berbasis Budaya Batak (PBMB3). Disertasi. Tidak dipublikasikan. Surabaya: PPs Universitas Negeri Surabaya.

Siregar, E. dan Nara. H. (2014). Teori Belajar dan Pembelajaran. Bogor: Ghalia Indonesia.

Sitorus, H. (2019). The Effect of Learning Strategy and Thinking Ability on The Students' Learning Outcomes in Economics Subject of XI Social Students in Senior High School State 1 in Pematang Siantar. Budapest International Research and Critics in Linguistics and Education (BirLE) Journal. p. 451-460.

Sumarni S, dkk. (2017). Pengaruh Model Pembelajaran Inkuiri Terbimbing Terhadap Hasil Belajar Kognitif Peserta Didik di SMA Negeri 01 Manokwari (Studi Pada Pokok Bahasan Kelarutan dan Hasil Kali Kelarutan). Jurnal Nalar Pendidikan Volume-5, No.1, 2017.

Surakhmad, W, (1990), Pengantar penelitian Ilmiah, Tarsito, Bandung.

Sudijono, A. (2012). Pengantar Statistik Pendidikan. Jakarta: Rajawali Press.

Sudjana, Nana. (2008). Dasar-dasar Proses Belajar Mengajar. Bandung: Sinar Baru Algensindo.

Sukiman.(2011). Pengembangan Media Pembelajaran.Yogyakarta: Pustaka Insan

Sumantri, dkk. (1999). Strategi Belajar Mengajar. Jakarta: Depdikbud Dirjen Dikti.

Sungkono.(2003). Pengembangan dan Pemanfaatan Bahan Ajar Modul dalam Proses Pembelajaran.Yogyakarta: FIP UNY.Hal: 7-1.

Suryabrata, Sumadi. (2012). Psikologi Pendidikan. Jakarta: Raja Grafindo Persada (Rajawali Press).

Syah, Muhibbin. (2008). Psikologi Pendidikan dengan Pendekatan Baru. Bandung: Remaja Rosdakarya.

Thamrin, A. (2003). Manajemen Produksi dan Industri kecil. Jakarta: Pusat Penerbitan Universitas Terbuka

Tawil. M. dan Liliasari. (2014). Ketrampilan-Ketrampilan Sains dan Implementasinya dalam Pembelajaran IPA. Makassar: Badan Penerbit UNM

Thiagarajan, S. Semmel, DS. Semmel, M.(1974). Instructional Development for Training Teachers of Exceptional Children. A Sourse Book. Bloomington: Central for Innovation on Teaching The Handicapped.

Trianto, (2007), Model Pembelajaran Terpadu dalam Teori dan Praktek, Jakarta: Prestasi Pustaka.

Trianto, (2010), Mengembangkan Model Pembelajaran Tematik, Jakarta: PT Prestasi Pustaka.

Trianto, (2011), Model Pembelajaran Terpadu Konsep, Strategi Dan Implementasinya Dalam Kurikulum Tingkat Satuan Pendidikan (KTSP), Jakarta : Bumi Aksara.

Trianto, (2014). Mendesain Model Pembelajaran Inovatif Progresif. Jakarta: Kenaba Perdana Media Group

Undang-undang No. 20 Tahun 2003 tentang Sistem Pendidikan Nasional. 
Undang-undang No. 25 Tahun 2000 Tentang Program Pembangunan Nasional (Propenas) Tahun 2000-2004.

Utomo, M.R., Hasruddin, Murad, A. (2020). Influence of Problem Based Learning Models (PBL) and Learning Motivation to Learn Outcomes and Student's Critical Thinking Skills Themes of Caring for Life in Class IV Primary School No 026609 Pujidadi Binjai. Budapest International Research and Critics in Linguistics and Education (BirLE) Journal Volume 3 (4): 1634-1643.

Vygotsky, L.S. (1934). Thought And Language, (A. Kozulen. Terj.) Cambridge. MA : MIT press. Dalam bukunya William Crain, Teori perkembangan / konsep dan aplikasi, (Yogyakarata: Pustaka Pelajar: 2007).

Wardani, I.G.A.K. (2008). Teknik Menulis Karya Ilmiyah. (cetakan ke-5). Depdiknas. Jakarta.

Wijaya. Juhana, (1988). Psikologi Bimbingan. Bandung: Eresco.

Wisudawati, A.W. dan Sulistyowati, E. (2014). Metodologi pembelajaran IPA. Jakarta: Bumi Aksara.

Widja, I Gede. (1989). Dasar-Dasar Pengembangan Strategi serta Model-Model Pengajaran Sejarah. Jakarta: Depdikbud Dirjen Dikti.

Woolfolk, Anita. (2009). Educational Psychologi Active Learning Edition. Boston: Allyn and Bacon.

Yanti, dkk.(2016), Pengembangan modul berbasis Guided inquirylaboratory (GIL) untuk meningkatkan literasi sains dimensi konten. Jurnal Inkuiri. ISSN: 2252-7893, 5, (2) 108-121. 